\title{
PROGRAM REHABILITASI SOSIAL BAGI PENYADANG DISABILITAS DI PANTI SOSIAL BINA DAKSA BUDI PERKASA PALEMBANG
}

\author{
Oleh \\ Metra Naibaho, Hetty Krisnani, \& Eva Nuriyah H
}

\begin{abstract}
ABSTRAK
Penyandang disabilitas dalam kehidupan nya sering menghadapi masalah masalah yang menghambat perkembangan kepribadian maupun mental nya. Banyak tekanan tekanan yang datang kepada penyandang disabilitas dalam menghadapi kehidupan nya. Misalnya adalah yang berasal dari keluarga, teman dekat maupun dari tengah tengah masyarakat. Dalam mengembangkan kemampuan nya, penyandang disabilitas perlu mendapatkan penguatan atau dukungan yang baik oleh masyarakat dimana dia tinggal.

Dalam hal ini perlu di adakan rehabilitasi sosial untuk memberikan dorongan kepada penyandang disabilitas supaya bisa mengembangkan kemampuan nya lebih lagi dan agar dapat melihat kelebihan meskipun memiliki kekurangan, namun bisa berdaya guna di tengah tengah masyarakat. Rehabilitasi sosial di harapkan memberikan pengaruh pada perkembangan mental penyandang disabilitas. Sangat banyak penyandang disabilitas yang tidak mampu untuk mengembangkan diri dan kemampuan karena tidak ada nya dukungan sosial dari masyarakat dan juga karena tidak adanya rehabilitasi sosial.

Melalui rehabilitasi sosial penyandang disabilitas diberikan materi materi berupa penguatan mental, pengembangan kemampuan, dan pengembangan kreativitas sehingga tidak dianggap sebagai manusia yang tidak produktif. Disamping itu di ajarkan untuk mampu menghadapi lingkungan masyarakat, keluarga dan sebagai nya agar ketika mereka masuk dan bergabung dengan masyarakat, tidak ada pandangan negatif terhadap penyandang disabilitas.
\end{abstract}

\section{PENDAHULUAN}

\section{Definisi Penyandang Disabilitas (Penyandang Cacat)}

Penyandang cacat menurut Undang-Undang Republik Indonesia Nomor 4 Tahun 1997 tentang Penyandang Cacat adalah setiap orang yang mempunyai kelainan fisik dan/atau mental, yang dapat mengganggu atau merupakan rintangan dan hambatan baginya untuk melakukan secara selayaknya, yang terdiri dari :

a. Penyandang cacat fisik;

b. Penyandang cacat mental;

c. Penyandang cacat fisik dan mental;

Penyandang diabilitas adalah mereka yang mempunyai kelainan atau gangguan pada alat gerak tubuh meliputi tulang, otot dan persendian baik dalam struktur maupun fungsinya sehingga tidak dapat melakukan kegiatan secara wajar. Penyandang disabilitas berhak untuk menjalani kehidupan mereka walau mereka memiliki keterbatasan. Disamping itu penyandang disabilitas memiliki hak yang sama dengan warga negara Indonesia lainnya.

Ini lah yang menjadi perhatian khusus dari pemerintah sesuai dengan undang undang negara republik Indonesia Nomor 4 tahun 1997 pasal 8 dimana "Pemerintah dan/atau masyarakat 
berkewajiban mengupayakan terwujudnya hak-hak penyandang disabilitas". Pemerintah dalam hal ini membangun panti sosial tersebut untuk mewujudkan nya, dimana dengan di bangun nya panti sosial ini akan membuat keterbatasan tersebut menjadi kelebihan sehingga penyandang disabilitas mampu memenuhi kebutuhan mereka nantinya.

Kecacatan adalah suatu kondisi dimana adanya kelainan fisik dan atau mental, yang dapat mengganggu atau merupakan rintangan dan hambatan bagi seseorang untuk melakukan aktivitas secara selayaknya. Mengacu, pada pasal 1, UU RI No. 23 Tahun 2002 tentang Perlindungan Anak, anak yang menyadang cacat adalah anak yang mengalami hambatan fisik dan/atau mental sehingga mengganggu pertumbuhan dan perkembangannya secara wajar.

Teori kecacatan menurut Perserikatan Bangsa-Bangsa, yaitu ;

Disability adalah keterbatasan atau kekurang mampuan untuk melaksanakan kegiatan secara wajar bagi kemanusiaan yang diakibatkan oleh kondisi impairment.

Menurut NASW (asosiasi pekerja sosial Amerika Serikat) :

Disability may be defined as a reduction in personal coping and adaptive function that causes significant limitation in overall daily living. (Kecacatan dapat didefinisikan sebagai keadaan berkurangnya fungsi pribadi dalam memenuhi kebutuhan dan daya penyesuaiannya sehingga menyebabkan keterbatasan dalam keseluruhan penampilan hidup sehari-hari).

\section{Ciri-ciri Penyandang Disabilitas}

1. Penyandang Cacat Fisik, yaitu individu yang mengalami kelainan kerusakan fungsi organ tubuh dan kehilangan organ sehingga mengakibatkan gangguan fungsi tubuh. Misalnya gangguan penglihatan, pendengaran, dan gerak.

2. Penyandang Cacat Mental, yaitu individu yang mengalami kelainan mental dan atau tingkah laku akibat bawaan atau penyakit. Individu tersebut tidak bisa mempelajari dan melakukan perbuatan yang umum dilakukan orang lain (normal), sehingga menjadi hambatan dalam melakukan kegiatan sehari-hari.

3. Penyandang Cacat Fisik dan Mental, yaitu individu yang mengalami kelainan fisik dan mental sekaligus atau cacat ganda seperti gangguan pada fungsi tubuh, penglihatan, pendengaran dan kemampuan berbicara serta mempunyai kelainan mental atau tingkah laku, sehingga yang bersangkutan tidak mampu melakukan kegiatan sehari-hari selayaknya.

\section{Klasifikasi Penyandang Disabilitas}

Menurut UU No. 4 Tahun 1997 tentang Penyandang Cacat, berbagai faktor penyebab serta permasalahan kecacatan, maka jenis-jenis kecacatan dapat di kelompokkan sebagai berikut :

1. Penyandang Cacat Fisik

a. Tuna Netra

Berarti kurang penglihatan. Keluarbiasaan ini menuntut adanya pelayanan khusus sehingga potensi yang dimiliki oleh para tuna netra dapat berkembang secara optimal.

b. Tuna Rungu/ Wicara

Tuna Rungu, ialah individu yang mengalami kerusakan alat atau organ pendengaran yang menyebabkan kehilangan kemampuan menerima atau menangkap bunyi serta suara. sedangkan Tuna Wicara, ialah individu yang mengalami kerusakan atau kehilangan kemampuan berbahasa, mengucapkan kata-kata, ketepatan dan kecepatan berbicara, serta produksi suara.

c. Tuna Daksa 
Secara harfiah berarti cacat fisik. Kelompok tuna daksa antara lain adalah individu yang menderita penyakit epilepsy (ayan), kelainan tulang belakang, gangguan pada tulang dan otot,serta yang mengalami amputasi.

d. Tuna Laras

Dikelompokkan dengan anak yang mengalami gangguan emosi. Gangguan yang muncul pada individu yang berupa gangguan perilaku seperti suka menyakiti diri sendiri, suka menyerang teman, dan lainnya.

e. Tuna Grahita

Sering dikenal dengan cacat mental yaitu kemampuan mental yang berada di bawah normal. Tolak ukurnya adalah tingkat kecerdasan atau IQ. Tuna grahita dapat dikelompokkan sebagai berikut :

1) Penyandang Cacat Mental Eks Psikotik:

- Eks psikotik penderita gangguan jiwa, sering mengganggu.

- Kadang masih mengalami kelainan tingkah laku.

2) Penyandang Cacat Mental Retardasi :

- Tuna Grahita Ringan (Debil)

Tampang dan fisiknya normal, mempunyai IQ antara kisaran $50 \mathrm{~s} / \mathrm{d} 70$. Mereka juga termasuk kelompok mampu didik, mereka masih bisa dididik (diajarkan) membaca, menulis dan berhitung, anak tunagrahita ringan biasanya bisa menyelesaikan pendidikan setingkat kelas IV SD Umum.

- Tuna Grahita Sedang (Embisil)

Tampang atau kondisi fisiknya sudah dapat terlihat, tetapi ada sebagian anak tuna grahita yang mempunyai fisik normal. Kelompok ini mempunyai IQ antara $30 \mathrm{~s} / \mathrm{d} 50$. Mereka biasanya menyelesaikan pendidikan setingkat kelas II SD Umum.

3) Tuna Grahita Berat (Idiot)

Kelompok ini termasuk yang sangat rendah intelegensinya tidak mampu menerima pendidikan secara akademis. Anak tunagrahita berat termasuk kelompok mampu rawat, IQ mereka rata-rata 30 kebawah. Dalam kegiatan sehari-hari mereka membutuhkan bantuan orang lain.

2. Penyandang Cacat Fisik dan Mental (Ganda)

Tuna Ganda

Kelompok penyandang jenis ini adalah mereka yang menyandang lebih dari satu jenis keluarbiasaan, misalnya penyandang tuna netra dengan tuna rungu sekaligus, penyandang tuna daksa disertai dengan tuna grahita atau bahkan sekaligus.

\section{Jenis jenis pengembangan keterampilan}

Penyandang disabilitas dalam hal ini agar tidak ketergantungan dengan lingkungan nya sebaik nya diberikan pelatihan pelatihan yang dapat membuat mereka menjadi produktif dan mampu memenuhi kebutuhan nya sendiri. Dengan memberikan pelatihan pelatihan dapat membuat mereka menjadi percaya diri dan bertanggung jawab untuk bisa memenuhi kebutuhan mereka dan tidak bergantung kepada orang lain di sekitar nya. Penyandang disabilitas menjadi tidak bergantung kepada orang lain dan tidak menjadikan kekurangan fisik menjadi suatu penghalang bagi mereka untuk dapat bekerja atau pun untuk berkretivitas. Dengan pelatihan mereka akan mampu mandiri, tidak bergantung pada orang lain bahkan bisa membantu orang lain dalam memenuhi kebutuhan hidup.

Departemen Sosial RI yang dalam hal ini merupakan departemen yang menanungi Panti Sosial Bina Daksa Budi Perkasa Palembang berusaha memberikan pelayanan yang terbaik untuk membantu mengembangkan percaya diri dan kreativitas penyandang disabilitas khusus nya di daerah 
Palembang. Penyandang disabilitas di panti sosial bina daksa di berikan berbagai pelatihan yang dapat menumbuh kembangkan kreativitas dan meningkatkan percaya diri mereka agar tidak merasa diasingkan. Selain itu penyandang disabilitas di bantu untuk membuka diri dan menjalani proses keterampilan tanpa di pungut biaya selama proses pelatihan.

Jenis bimbingan latihan dan keterampilan meliputi :

1. Penjahitan baik dilakukan oleh laki laki atau perempuan. Pada pelatihan penjahitan akan di ajarkan bagimana untuk menjahit dengan mesin dan bisa untuk menghasilkan suatu barang jadinya.

2. Elektro meliputi latihan untuk memperbaiki barang barang elektronik.

3. Las Listrik/ Karbit seperti membuat gerbang atau pun menghasilkan barang barang yang terbuat dari besi.

4. Pertanian terpadu berisi pelatihan bagimana cara cara untuk bertani secara benar dan bisa menghasilkan dengan baik dan nilai jual tinggi.

5. Komputer berisi pelatihan menjadi seorang yang bisa mengerti dan melakukan aktivitas yang berkaitan dengan komputer.

6. Otomotif Motor yaitu pelatihan agar bisa memperbaiki mesin ataupun body motor.

7. Kerajinan Wanita dikhusus kan untuk wanita dimana pelatihan nya berisi pelatihan untuk membuat kerajinan yang berdaya guna seperti membuat tas, makanan makanan dan masih banyak lagi.

8. Salon

Disamping itu ada bimbingan pemakaian alat bantu :

1. Ergosykly (Sepeda Statis) alat untuk menguatkan otot kaki

2. Rowing Machine alat untuk menguatkan tangan

Disamping kegiatan kegiatan di atas masih ada kegiatan ekstra kulikuler berupa tata boga dan kesenian.

\section{Pengertian rehabilitasi}

Kebutuhan Penyandang Disabilitas

Penyadang disabilitas memiliki kebutuhan yang tidak berbeda dengan manusia normal pada umum nya, hanya saja mereka memiliki keterbatasan yang dimiliki sehingga mereka sulit memenuhi kebutuhan nya. Kebutuhan penyandang disabilitas seperti:

1. Kebutuhan fisik

Yaitu kebutuhan akan sandang, pangan, papan dan kesehatan. Apabila kebutuhan fisik ini dapat di penuhi akan memungkinkan penyandang disabilitas untuk melakukan aktivitas lainnya karena sudah ada energy yang dapat digunakan untuk melakukan aktivitas sehari hari.

2. Kebutuhan psikologis

Didalam nya termasuk kebutuhan akan rasa aman, kebutuhan akan merasa bebas dan merdeka. Kebutuhan akan rasa aman yaitu mereka bebas melakukan aktivitas mereka tanpa ada rasa takut atau intimidasi dari orang lain yang dapat menurunkan tingkat keinginan mereka untuk melakukan aktivitas.

3. Kebutuhan sosial

Yang termasuk di dalam adalah rasa ingin di hargai dan diakui keberadaan nya. Dalam hal ini, penyandang disabilitas juga ingin di hargai orang meskipun mereka memiliki keterbatasan dan mereka merasa diakui karena mereka ingin di ikut sertakan oeleh masyarakat dan juga ingin di akui keberadaan nya bukan sebaliknya. 


\section{Permasalahan Yang di Alami Oleh Penyandang Disabilitas}

Penyandang disabilitas sangat erat kaitan nya dengan permasalahan. Baik itu yang berasal dari lingkungan maupun dari dalam dirinya sendiri. Menurut Ngadijo (1989:19), permasalahan permasalahan tersebut adalah sebagai berikut:

a. Permasalahan pribadi

1. Aspek jasmani

Permasalahan ini berkaitan dengan hilang nya organ tubuh yang mengakibatkan mobilitas jasmani menjadi kurang dan aktivitas sehari harinya menjadi terganggu.

2. Aspek mental

Hambatan mental yang timbul pada penyandang disabilitas tubuh antara lain sifat rendah diri, mudah tersinggung, apatis dna kurang percaya diri pada kemampuan nya.

3. Aspek sosial kemasyarakatan

Dengan kedisabilitasan yang di sandangnya, seseorang kurang dapat mengikuti kegiatab yang di adakan di lingkungan masyarakatnya, sehingga hubungan pergaulan dengan masyarakat atau pihak lain menjadi terbatas. Keterbatasan juga dipengaruhi adanya nilai masyarakat yang memandang penyandang disabilitas tubuh sebagai obyek yang harus di kasihani.

4. Aspek ekonomi

Penyandang disabilitas pada umum nya sulit untuk mendapat pekerjaan yang dapat menjadi sumber penghidupan. Sulit bagi penyandang disabilitas untuk menemukan pekerjaan yang layak.

5. Aspek hukum

Di Indonesia penyandang disabilitas tidak mendapatkan advokasi yang baik, terbukti dengan masih banyak nya perusahaan yang tidak memberikan porsi bagi penyandang disabilitas untuk bekerja di dalam nya.

b. Permasalahan keluarga

Masih ada keluarga yang memandang bahwa apabila ada anggota keluarga yang disabilitas maka dianggap bahwa anak yang disabilitas tersebut adalah anak yang membawa musibah dan membuat malu keluarga.

c. Permasalahan masyarakat

Penyandang disabilitas juga merupakan anggota masyarakat dan ikut berkontribusi di dalam nya. Dalam hal ini, penyandang disabilitas memiliki kekurangan dan tidak dapat melakukan fungsi dan kewajiban dirinya sebagai seorang anggota masyarakat.

\section{Tinjauan mengenai rehabilitasi}

Pengertian rehabilitasi

Rehabilitasi didefinisikan sebagai "satu program holistik dan terpadu atas intervensi-intervensi medis, fisik, psikososial, dan vokasional yang memberdayakan seorang (individu penyandang cacat) untuk meraih pencapaian pribadi, kebermaknaan sosial, dan interaksi efektif yang fungsional dengan dunia" (Banja,1990:615).

Menurut Soewito dalam (Sri Widati, 1984:5) menyatakan bahwa:

Rehabilitasi penderita cacat merupakan segala daya upaya, baik dalam bidang kesehatan, sosial, kejiwaan, pendidikan, ekonomi, maupun bidang lain yang dikoordinir menjadi continous process, dan yang bertujuan untuk memulihkan tenaga penderita cacat baik jasmaniah maupun rohaniah, untuk menduduki kembali tempat di masyarakat sebagai anggota penuh yang swasembada, produktif dan berguna bagi masyarakat dan Negara.

Suparlan (1993:124) mengemukakan bahwa rehabilitasi merupakan suatu proses kegiatan untuk memperbaiki kembali dan mengembangkan fisik, kemampuan serta mental seseorang sehingga orang itu dapat mengatasi masalah kesejahteraan sosial bagi dirinya serta keluarganya. 
Menurut Peraturan Pemerintah No.36/1980, tentang Usaha Kesejahteraan Sosial bagi Penderita Cacat, rehabilitasi didefinisikan sebagai suatu proses refungsionalisasi dan pengembangan untuk memungkinkan penderita cacat mampu melaksanakan fungsi sosialnya secara wajar dalam kehidupan bermasyarakat.

Sedangkan menurut PP No.72/1991 tentang PLB dan SK Mendikbud No.0126/U/1994 pada lampiran 1 tentang Landasan, Program, dan Pengembangan Kurikulum Pendidikan Luar Biasa, disebutkan bahwa rehabilitasi merupakan upaya bantuan medik, sosial, dan keterampilan yang diberikan kepada peserta didik agar mampu mengikuti pendidikan. Usaha rehabilitasi merupakan proses rangkaian kegiatan yang dilakukan oleh petugas rehabilitasi secara bertahap, berkelanjutan, dan terus menerus sesuai dengan kebutuhan.

\section{Tujuan Rehabilitasi}

Dalam Undang-undang Nomor 4 tahun 1997 dijelaskan bahwa Rehabilitasi diarahkan untuk memfungsikan kembali dan mengembangkan kemampuan fisik, mental dan sosial penyandang cacat agar dapat melaksanakan fungsi sosialnya secara wajar sesuai dengan bakat, kemampuan, pendidikan dan pengalaman.

Tujuan utama rehabilitasi adalah membantu penca mencapai kemandirian optimal secara fisik, mental, sosial, vokasional, dan ekonomi sesuai dengan kemampuannya. Ini berarti membantu individu tersebut mencapai kapasitas maksimalnya untuk memperoleh kepuasan hidup dengan tetap mengakui adanya kendala-kendala teknis yang terkait dengan keterbatasan teknologi dan sumbersumber keuangan serta sumber-sumber lainnya.

Tujuan rehabilitasi adalah terwujudnya anak/peserta didik berkelainan yang berguna (usefull). Pengertian berguna tersebut mengandung dua makna, yaitu: Pertama, peserta didik mampu mengatasi masalah dari kecacatannya, dapat menyesuaikan diri terhadap kekurangan-kekurangannya, serta mempunyai kecekatan-kecekatan sosial dan vokasional.

Kedua, pengertian berguna juga mengandung makna bahwa peserta didik memiliki kekurangan-kekurangan. Artinya kondisi pencapaian maksimal mungkin tidak sama dengan anakanak normal, dan dalam kondisi minimal peserta didik cacat tidak bergantung pada orang lain dalam mengurus dan menghidupi dirinya.

Di samping itu, aspek berguna juga dapat mencakup self realization, human relationship, economic efficiency, dan civic responsibility. Artinya, melalui kegiatan-kegiatan rehabilitasi, peserta didik cacat diharapkan:

a. Dapat menyadari kelainannya dan dapat menguasai diri sedemikian rupa, sehingga tidak menggantungkan diri pada orang lain (self realization).

b. Dapat bergaul dan bekerjasama dengan orang lain dalam kelompok, tahu akan perannya, dan dapat menyesuaikan diri dengan perannya tersebut. Dapat memahami dan melaksanakan tugasnya dengan baik. Dapat mengerti batas-batas dari kelakuan, dapat menyesuaikan diri dengan lingkungan sosial, etika pergaulan, agama, dan tidak memisahkan diri, tidak rendah diri, dan tidak berlebihan, serta mampu bergaul secara wajar dengan lingkungannya (human relationship)

c. Mempunyai kemampuan dan keterampilan ekonomis produktif tertentu yang dapat menjamin kehidupannya kelak di bidang ekonomi (economic efficiency). Di samping itu kemampuan keterampilan menggunakan organ gerak tertentu yang sudah terampil (misalnya mampu menggunakan kursi roda) diusahakan tetap terjaga keterampilannya.

d. Memiliki tanggung jawab dan mampu berpartisipasi terhadap lingkungan masyarakat, minimal ia tidak mengganggu kehidupan masyarakat (civic responsibility).

Disamping mengadakan pelatihan, Panti Sosial Bina Daksa Budi Perkasa mengadakan rehabilitasi sosial penyandang disabilitas, dimana dengan adanya rehabilitasi sosial di harapkan 
mampu mengembangkan percaya diri mereka dan mental penyandang disabilitas yang ada di Panti Sosial Bina Daksa Budi Perkasa Palembang.

Pada umumnya, rehabilitasi yang diberikan kepada penyandang disabilitas berfungsi untuk tindakan pencegahan (preventif), penyembuhan (kuratif), atau pemulihan/pengembalian (rehabilitatif), dan pemeliharaan/penjagaan (promotif). Disamping memberikan pelatihan, diberikan juga rehabilitasi sosial, dimana rehabilitasi sosial berfungsi untuk mengembalikan keberfungsian sosial penyandang disabilitas.

Panti Sosial Bina Daksa Budi Perkasa memiliki 4 orang pekerja sosial yang memberikan rehabilitasi sosial terhadap penyandang disabilitas. Para penyandang disabilitas beraneka ragam. Ada yang tidak bisa melihat (tuna netra) ada juga yang salah satu anggota tubuh nya tidak lengkap (misal nya adalah tangan atau kaki). Setiap penyandang disabilitas tentu memiliki kebutuhan yang berbeda. Misal nya adalah seorang tuna netra perlu untuk di berikan rehabilitasi sosial dengan memberikan motivasi berupa pemberian materi materi yang membangkitkan motivasi tuna netra tersebut. Motivasi tersebut misal nya adalah mengadirkan seorang tuna netra yang sudah sukses dan diharapkan mampu memotivasi tuna netra tersebut untuk dapat mengembangkan mental nya sehingga dia bisa ikut sukses.

Namun di Panti Sosial Bina Daksa Budi Perkasa penyandang disabilitas beragam jenis dan pekerja sosial memberikan rehabilitasi sosial secara menyeluruh. Perlakuan terhadap penyandang disabilitas berbeda beda dan tidak bisa di samakan. Dengan di lakukan nya kesamaan rehabilitasi di Panti Sosial Bina Daksa Budi Perkasa maka pengembangan mental penyandang disabilitas di panti sosial ini tidak akan berhasil dengan benar dan baik.

Ini lah yang menjadi permasalahan, perlakuan yang sama terhadap beragam penyandang disabilitas di Panti Sosial Bina Daksa Budi Perkasa tidak menghasilkan sesuatu perubahan yang signifikan terhadap penyandang disabilitas di panti tersebut. Tuna netra seharus nya diberikan rehabilitasi sosial yang berbeda dari penyandang disabilitas lain nya, hal ini tentunya akan lebih efektif dan membuat para penyandang disabilitas mengembangkan mental untuk dapat mengembangkan kreativitas nya. ketika di kelas, membuat kerajinan tangan seperti accessories, membuat telur asin, budi daya jamur dalam hal proses penanaman, penyiraman, sampai penjualan.

Aspek kekeluargaan melekat pada yayasan tersebut, adanya nilai yang baik di masyarakat membuat yayasan tersebut mendapatkan simpati dari masyarakat luas sehingga banyak orang yang berkunjung dan melihat bagaimana aktivitas pengembangan yang dilakukan oleh yayasan tersebut. Komitmen dalam melayani dan kesadaran akan pentingnya pendidikan bagi penyandang disabilitas merupakan aset utama dalam keberlangsungan program.

Yayasan ini memiliki tanggung jawab dengan memberikan pelayanan kepada tuna netra ganda. kondisi dimana setiap penyandangnya memiliki dua atau lebih hambatan, dengan hambatan utama pada penglihatan (buta atau low vision). Belum banyak lembaga yang mewadahi para penyandang disabiltas dengan dua atau lebih hambatan. Penyandang disabilitas yang berada di yayasan ini berjenis laki-laki dan perempuan dengan jumlah kurang lebih 68 siswa, dengan staff, pegawai berjumlah 52 orang, serta sukarelawan yang membantu proses pemberian pelayanan kepada para penyandang. Tidak semua penyandang menetap di yayasan ini, ada juga penyandang yang diantar dan dijemput oleh keluarga. Aspek pembiayaan juga sangat beragam, ada yang menggunakan biaya mandiri, subsidi, ataupun bebas dari biaya.

\section{PEMBAHASAN}

Penyandang disabilitas adalah mereka yang memiliki kelainan alat gerak baik meliputi tulang, alat sendi gerak baik dalam struktur maupun fungsinya. Dalam hal ini struktur maupun fungsi tubuh yang ada pada diri seseorang mengalami kelainan atau bahkan tidak ada. Dalam hal ini hal tersebut menggangggu aktivitas dari seseorang sehingga tidak dapat melakukan aktivitas layak nya manusia pada umum nya. 
Penyandang disabilitas dalam keseharian nya seringkali mendapatkan gangguan dalam menjalankan aktivitasnya, baik yang berasal dari dalam diri mereka sendiri, dari lingkungan, dari keluarga maupun dari teman teman sekitarnya. Dari dalam diri sendiri penyandang disabilitas bahkan sudah ada pemikiran bahwa dia memiliki kekurangan dan tidak mungkin dapat menyesuaikan diri dengan lingkungan nya. Ada yang merasa minder, putus asa dan malah memisahkan diri dengan lingkungan nya.

Dari lingkungan keluarga tentu ada beberapa keluarga yang tidak menerima dengan baik keadaan dari anggota keluarga mereka yang mengalami disabilitas tersebut. Ada keluarga yang tidak mengharapkan keberadaan si penyandang disabilitas sehingga dia malah tertekan dan menjadi susah dalam mengekspresikan diri dan mengembangkan kemampuannya.

Dari lingkungan, penyandang disabilitas kerap kali mendapatkan stigma negatif dari lingkungan sekitarnya, misalnya adalah ketika penyadang disabilitas berada di lingkungan nya banyak yang menganggap jika orang tersebut hanyalah orang yang menyusahkan dan tidak berdaya guna bagi lingkungan sekitar. Bahkan ada juga penyandang disabilitas yang menjadi bahan bulliying oleh orang di lingkungan nya.

Tidak dapat di pungkiri bahwa penyadang disabilitas sangat banyak mendapatkan tekanan tekanan dari dirinya sendiri bahkan dari lingkungan sekitarnya. Ini lah yang menjadi perhatian pekerja sosial di dinas sosial provinsi Sumatera Selatan. Selain memberikan pengembangan kreativitas bagi penyandang disabilitas, pekerja sosial juga memberikan rehabilitasi sosial bagi penyandang disabilitas di provinsi Sumatera Selatan. Pekerja sosial disamping memberikan pengembangan keterampilan namun juga memberikan program rehabilitasi sosial. Rehabilitasi sosial menjadi jawaban akan permasalahan yang dialami oleh penyandang disabilitas.

Rehabilitasi sosial dalam hal ini diberikan di sela sela kegiatan pengembangan kreativitas. Pengembangan kreativitas yang di maksud adalah latihan keterampilan untuk memberdayagunakan penyandang disabilitas. Bagi perempuan diberikan pelatihan salon dan kursus kecantikan, bagi laki laki diberikan pelatihan seperti las karbit dan elektronik.

Program di atas diberikan agar penyandang disabilitas memiliki keterampilan dan mampu mengembangkan dirinya supaya tidak menjadi beban bagi orang lain. Diharapkan setelah keluar dari panti, mereka dapat memenuhi kebutuhan mereka sendiri dengan mempergunakan bekal yang telah diterima oleh mereka ketika masa pelatihan. Atau dengan kata lain mereka mempraktikkan apa yang mereka dapatkan selama pelatihan diberikan.

Dengan mengadakan pelatihan, penyandang disabilitas menjadi orang orang yang mampu mengembangkan kemampuan dan tidak bergantung pada orang lain. Hal ini lah yang menjadikan mereka meningkat percaya dirinya dan mampu mengembangkan dirinya.

Dalam mengembangkan dirinya, banyak sekali rintangan yang di hadapi oleh penyandang disabilitas. Tidak lah mudah bagi penyadang disabilitas dalam menjalani kehidupan nya, banyak faktor fakor yang menghambat dalam perjalanannya. Ini lah yang menjadi konsentrasi pekerja sosial, kemauan untuk berkembang terkadang tidak hanya berasal dari diri individu melainkan ada yang berasal dari luar diri individu tersebut. Misalnya saja, ada dorongan dari seorang individu untuk mengembangkan dirinya, namun dorongan dari dalam dirinya itu di rasa tidak cukup dan butuh dorongan dari orang orang sekitarnya.

Keinginan penyandang disabilitas akan hal ini di jawab oleh pekerja sosial dengan memberikan rehabilitasi sosial. Rehabilitasi sosial adalah program yang di canangkan untuk mengembalikan kondisi semula dimana tujuan dari rehabilitasi sosial ini adalah memulihkan keberfungsian sosial penyandang disabilitas cara nya adalah dengan memberikan dan meningkatkan rasa percaya diri agar mampu keluar dan dapat mengatasi masalah yang dialaminya. Melalui rehabilitasi sosial diharapkan penyandang disabilitas mampu menunjukkan jati diri dan kemampuannya di depan banyak orang. 
Salah satu penyadang disabilitas yang bernama Peni berasal dari desa pelabuhan dalam kecamatan pemungutan kabupaten ogan ilir yang mengalami kebutaan sejak lahir diberikan kesempatan oleh pemerintah untuk masuk dan mengikuti kegiatan di panti sosial kemudian mendapatkan rehabilitasi sosial mengungkapkan bahwa setelah mendapatkan rehabilitasi sosial banyak sekali mamfaat yang didapat, misal nya sebelum mendapat rehabilitasi sosial dia adalah sosok pemalu, tidak percaya diri dan bahkan putus asa dan di tinggalkan oleh teman teman sebayanya.

Kemudian klien ini diberikan kesempatan oleh pemerintah ogan ilir untuk mendaftar di panti sosial Bina Daksa Budi Perkasa Palembang, selain mendapatkan pengembangan kreativitas, klien ini juga mendapatkan program rehabilitasi sosial.

Ada suatu perbedaan yang di rasakan oleh klien tersebut. Pada mulanya memang sulit baginya untuk melakukan adaptasi dan sulit untuk mengeluarkan bakat bakat nya. Pada mulanya klien ini masih lebih banyak berdiam diri dan masih memikirkan bagaimana respon masyarakat sekitar tentang dirinya. Pada dasarnya dia berasal dari keluarga yang tingkat ekonomi nya cukup rendah, apalagi ditambah dengan keadaan klien yang secara fisik kurang. Hal ini semakin menambah banyak nya tekanan yang diterima nya. Baik itu konflik dari batin nya sendiri maupun yang berasal dari keluarga, teman teman dan lingkungan sekitarnya.

Banyak dari penyadang disabilitas mengalami hal serupa ketika mulai memasuki panti sosial. Banyak yang sulit beradaptasi, sulit menerima kekurangan fisik dan mental, sulit juga untuk memotivasi dirinya sendiri. Ini lah yang dilihat oleh pekerja sosial di panti sosial tersebut.

Rehabilitasi sosial dilakukan oleh pekerja sosial dengan melakukan kegiatan kegiatan seperti sharing kelompok yang di dalam nya akan dilakukan penguatan penguatan oleh anggota dalam kelompok itu sendiri maupun yang diberikan oleh pekerja sosial kepada penyandang disabilitas.

Disamping itu pekerja sosial terkadang mendatangkan narasumber yang merupakan salah satu penyadang disabilitas yang pernah merasakan seperti apa yang mereka rasakan namun tetap melakukan kegiatan dan aktivitas yang dapat membuat dia tidak di anggap rendah oleh masyarakat bahkan masyarakat menerima dengan baik keadaan nya dan bisa dikatakan sukses setelah keluar dari panti sosial.

Mendatangkan seorang narasumber yang demikian bisa membangkitkan semangat penyandang disabilitas untuk memotivasi dirinya untuk bisa seperti narasumber atau bahkan melebihi narasumber. Karena mereka akan memotivasi diri mereka untuk bisa seperti narasumber.

\section{SIMPULAN DAN SARAN}

Pekerja sosial dalam menghadapi tuna daksa bertidak sebagai pemberi rehabilitasi sosial. Dimana pekerja sosial tidak bertindak dalam pengembangan kreativitas penyandang disabilitas, namu lebih kepada pemberian rehabilitasi, dimana penyandang disabilitas diberikan dorongan dorongan dan semangat serta memberikan pengetahuan bahwa mereka masih banyak orang diluar yang memiliki keterbatasan tapi mengembangkan kemampuan nya.

Pekerja sosial harusnya lebih jeli melihat keadaan penyandang disabilitas, lebih memahami apa yang menjadi "need" nya, sehingga akan lebih mudah memberikan rehabilitasi bagi penyandang disabilitas tersebut.

\section{Buku:}

\section{DAFTAR PUSTAKA}

Penyandang Disabilitas Berdasarkan Klasifikasi International Classification of Functioning for Disability and Health (ICF) by Dr. Marjuki, M.Sc., Kepala Badan Pendidikan dan Penelitian Kesejahteraan Sosial Departemen Sosial Republik Indonesia

Oliver, Michael. 1991. Social Work Disabled People and Disabling Environments. London: Jessica Kingsley Publishers. 
Sunaryo.1995. Dasar-Dasar Rehabilitasi dan Pekerjaan Sosial. Jakarta: Depdikbud Dirjen Dikti PPTG.

Payne, James S, Mercer, Cecil D, and Epstein, Michael H. 1982. Education and Rehabilitation Techniques. Homewood Illinois: The Dorsey Press.

Parker, Randall M, Szymanski, Edna Mora, and Patterson, Jeanne Boland. 2005. Rehabilitation Counseling Basics and Beyond. Austin Texas: PRO-ED Inc.

Drs.Sumanto.M.A., 1995 , Metodologi Penelitian Sosial Dan Pendidikan, Yogyakarta : Andi Offset.

Hadi, Sutrisno, 1997. Metodologi Research, Yogyakarta : Andy Offset.

Winarno, Surachmad, 1995. Metode Penelitian, Bandung: Tarsito.Williams Richard. 2007. Mental Health Interventions and Services for Vulnerable Children and Young People. Jessica Kingsley Publisher: London and Philadelphia

Choiri, A Salim. 1997. Penyandang Cacat Tubuh Dan Kebutuhan Rehabilitasi: Suatu Potret Hasil Penelitian Masalah Kecacatan. Jurnal Rehabilitasi dan Remidiasi Nomor: 16 Th. 2-1997. Surakarta: PRRR- Lembaga Penelitian Universitas Sebelas Maret

Konvensi International Hak-Hak Penyandang Cacat (International Convention on the Rights of Persons With Disabilities)

Pedoman Pelayanan Kesehatan Anak di Sekolah Luar Biasa, 2010

Services for People, U.S. Departement of Health, Education, and Welfare, Washington, D.C., 1968)

Penelitian:

Laporan Hasil Kajian Pelaksanaan Bimbingan Sosial Bagi Penyandang Cacat Tubuh di BBRSBD Prof. Dr. Soeharso Surakarta tahun 2009

\section{Rujukan Elektronik:}

http://penyandangdisabilitas.wordpress.com/2009/05/22/klasifikasi-penyandang-disabilitas-2/ http://budiperkasa.depsos.go.id/modules.php?name=News\&file=article \&sid=18

http://en.wikipedia.org/wiki/Personal_development 